\title{
Business Japanese Teaching Innovation Research
}

\author{
Wang Shanshan \\ Foreign Language Department \\ Jilin Business and Technology College \\ Changchun, China \\ 182076127@qq.com
}

\begin{abstract}
With the continuous development of economy, there are more and more countries involving in international trade and language becomes a more and more important tool in international communication. With the rise of Japan and its increasing important role in the whole world, Japanese also becomes more and more useful and popular around the world, which means more and more requirements should be made for business Japanese teaching. It is worthy of thinking how to teach business Japanese course innovatively according to the change of epoch. College teachers, based on social needs for talents, are supposed to think seriously about the exploration and innovation of college business Japanese combining with the specific situation of students so as to improve the practicability of business Japanese course. After analyzing the existing problems of business Japanese teaching in Chinese colleges, it is found that traditional business Japanese teaching methods have been unable to meet the needs of students and should be enriched because only innovation of teaching methods can meet the social demand for business Japanese talents. Accordingly, teaching innovation strategies are put forward to make up for the problems of business Japanese teaching at present and enable students to meet the demands of business Japanese activities in society.
\end{abstract}

Keywords—Business Japanese; Teaching; Innovation

\section{INTRODUCTION}

With increasingly obvious trend of economic globalization, China and Japan's economic and cultural exchanges become more and more frequent. With the rising activities of the multinational culture, there are expanding areas of cooperation between Japan and our country. As a result, the demand for business Japanese talents is also on the rapid rise. It is necessary and urgent for Chinese colleges to positively develop business Japanese course consistent with China's national conditions for the cultivation of more excellent Japanese talents.

\section{OVERVIEW OF DEMAND FOR BUSINESS JAPANESE TALENTS}

With the unceasing enhancement of China's diplomatic level, China has more and more business trades with Japan. Under this background, business Japanese becomes a more and more popular course in Chinese colleges. According to related survey in 2015, among all the colleges in our country, business Japanese course covers more than 600 colleges, taking up 30\% of the total number of Japanese course. The total number of students majored in business Japanese has reached up to more than 150000. In the next five years, the number of national college students majored in business Japanese will be continuously growing by $10 \%$ per year[1]. Universities set up the business Japanese majors, which conforms to the demand of the market. Students can have a good job after graduation, which also meets the need of the actual economic development. According to the relevant departments' investigation statistics, in the near future, China's demand for foreign language and foreign trade talents will add up to more than ten million. For quite a long time in the past, as long as it is Japanese graduate, it is easy to find a good job in Japanese companies. However, combining with the current situation and the deepening of the reform and opening up in China, Japanese companies have set a higher requirement for talents, namely, talents are supposed to have a certain application ability, understand the process of economic trade and master professional knowledge. Through the analysis of the geographical position distribution of the Japanese professional education, it can be found that colleges with Japanese majors are mostly concentrated in coastal areas, including Guangdong, Jiangsu and other regions, however, the outback regions are relatively fewer, meaning that the eastern coastal developed areas have a greater demand of business Japanese talents[2].

\section{Existing Problems of Business JAPANESE TEACHING IN CHINA}

Since 1990, many Japanese companies are branched into China, there are more and more economic and trade activities between the two countries. According to the data, since 2006, China has become the largest trading partner of Japan after World War II. It has been the 43th anniversary of diplomatic relations between the two countries in 2016[3]. With the frequent exchange of visits between the leaders of the two countries, the relationship between the two countries is closer, which has comprehensively promoted the bilateral trade and provides substantial employment opportunities for talents majored in Japanese, so as to offers a new challenge to cultivate Japanese talent in the new era.

Business Japanese is a comprehensive interdisciplinary, including Japanese linguistics, trade and other aspects of knowledge. Combining the teaching case, due to the teachers' lack of experience and old-fashioned teaching model, most business Japanese teaching only stays on theoretical knowledge, which can't make students fully understand the Japanese enterprise culture and the Japanese enterprise atmosphere. Based on this, the author summarizes the following problem of business Japanese teaching. 


\section{A. Unreasonable design of curriculum}

At present, many colleges, in order to meet the needs of modern society for business Japanese talents, has set up business Japanese courses. At the same time, most colleges' lack of rational cognition about the course and thinking about how to cultivate the business Japanese talents to meet the social needs and knowing about what kind of professional quality and knowledge business Japanese talents need to be provided with makes them blindly set courses related to Japanese. In such cases, it is unable to guarantee the quality of Japanese teaching and also cannot develop business Japanese talents to fit the development of China's national conditions. That curriculum is unreasonable also leads to the unclear teaching goal of business Japanese, cause the duplicate phenomenon of business Japanese in terms of content, and finally causes the lack of systematic and holistic features in business Japanese course. Courses including business Japanese session, Japanese business etiquette and business communication, for example, lack of professional knowledge learning of business Japanese system, which makes students fail to fully grasp the systematic knowledge of Japanese business and cannot enhance the students' ability to adapt to the society in practice. Developing business Japanese talent cultivation scheme should be fully combined with market research of Japanese enterprises, need to understand the language accomplishment related to the business and formulate an all-round training plan.

\section{B. The quality of business Japanese teacher to be improved}

Combined with the present situation, business Japanese teachers' comprehensive quality in our country is low. Because of the lack of business experience, business Japanese teaching only stays in theoretical stage, that is to say, most business Japanese teachers focus mainly on Japanese theoretical knowledge and research with theoretical knowledge in colleges. Students, undoubtedly, will involve directly into Japanese teaching after graduation. However, few people are engaged in trade related work due to the lack of related experience. Through investigation, many business Japanese teachers in our country lack of knowledge of business etiquette and business trade, leading to business Japanese teachers to only focus on the teaching of theoretical knowledge and fail to combine teaching with the actual business activities and operate meaningful guidance to students, so it is difficult to make the students fully understand the practice application of business Japanese and causes students' lack of communicative competence in intercultural activities.

\section{The backward teaching method}

The traditional education and teaching is a process of instilling knowledge. The direct result is that business Japanese teaching remains largely centered on teachers and teachers and students' relations turn into a simple and mechanical "teaching" and "acceptation". Teachers speak more but students practice less, which is difficult to improve the students' practical ability. They lack of learning initiative and enthusiasm and get used to this "cramming" teaching mode, namely, only in accordance with the arrangement of the teacher. As a result, they lack of independent innovation ability and fail to develop a high learning efficiency.
Combining with the current situation, business Japanese teachers in our country still adopt the traditional teaching method with teaching form still confined to the podium, blackboard and textbooks and teaching method still staying in the teachers' oral lecture and students' passive listening, which leads to the lack of adequate communication between teachers and students and fails to stimulate students' learning initiative of business Japanese and improve their creativity. Business Japanese teachers focus the teaching content mostly on the textbook explanation, which can only let students understand Japanese theoretical knowledge but is unable to improve the comprehensive quality and Japanese communication skills.

\section{TEACHING INNOVATION EXPLORATION FOR CONTEMPORARY BUSINESS JAPANESE TEACHING}

In the teaching process, teachers should understand the fundamental aim of teaching, because the purpose of setting business Japanese business course is to make students become business talents. In this view, business Japanese is not a pure course of Japanese and doesn't belong to the category of linguistics. To compare with linguistics, it pays more attention to the process of practical application. In the teaching process, business Japanese needs to pay attention to the organic combination of language and business courses, so as to create vivid teaching situation and a simulated business environment for students. In this way, it can improve students' understanding of the business activities, fully mobilize students' learning initiative and enthusiasm and make the students master the basic communication skills and business theory.

\section{A. Defining the main goal of business Japanese talent cultivation}

Business Japanese's demand for students is not only fully grasping the theory knowledge of Japanese, but also knowing something about interpersonal knowledge, improving the comprehensive quality of business Japanese and strengthening students' practical application ability of business Japanese, which can include practical significance for teaching and deepen students' understanding of business trade knowledge and business culture. Before developing a plan of cultivating talents of business Japanese, teachers should clear the main goal of the business Japanese talent cultivation and reasonably arrange business Japanese teaching according to the target setting.

\section{B. Update the course content and teaching plans combining with the actual situation}

The current economic development speed is getting faster and faster. If teachers continue using the out-of-date cases in teaching material, it is easy to cause students to lose interest in learning the curriculum content, so classroom teaching cases should be updated in a timely manner. Although this increases the amount and difficulty of course preparation, it is beneficial to improving teachers' teaching quality and students' learning interest and efficiency. The update of cases should concern about the economic dynamic balance between the two countries, aiming to let students understand the status of the two countries' economic development and the future trends at 
the same time, so as to be prepared for the future jobs. Teachers, when preparing for cases, should consider the applicable method in business Japanese in line with the actual situation in China. The analysis of cases should focus on heuristic education, which makes students think more and lets students solve practical problems using the learned knowledge and skills. In addition, in classroom teaching, teachers should be encouraged to use multimedia teaching and play courseware, pictures, video, etc., letting students learn knowledge more intuitively[4].

\section{Stepping up efforts to business Japanese teacher's training}

Considering business Japanese teachers' lack of business experience, we need to hire senior business Japanese talents to experience deliver lectures in college and intensify the business Japanese teacher's training. Training content includes professional quality, business trade, marketing and finance related training, actively encouraging teachers to participate in commercial activities, making teachers understand the need of the society in a timely manner, supplementing the teacher's basic knowledge of business, improving the teacher's business skills and update their professional knowledge and skills, enriching their own professional field and making up for the inadequacy in practical experience. It is beneficial to making necessary adjustment of teaching content and promoting to cultivate more outstanding Japanese business talents to meet the needs of contemporary development. In addition, colleges can actively establish cooperation relationship with enterprises, promote teachers to complete task of transformation and arrange teachers to learn professional practice in the first line enterprises, in which enterprise expert puts forward some improvement opinions accordingly, finally to complete the dual reform of teaching content and teaching method.

\section{Adopting innovative teaching method}

Business Japanese talent training in colleges not only relies on teachers, but also is related to teaching form. It is necessary to change single teaching form and import enterprises technology appropriately. The specific operation method is:

First, import the Japanese corporate culture. Language expression ability is the foundation of interpersonal communication but language ability does not mean having the ability to cross-cultural communication. Teachers, in the teaching of the past, focused on the aspects such as vocabulary, grammar and professional term, and neglected the introduction to Japanese corporate culture knowledge, causing students to learn simple language far from the cultural background and become very difficult to achieve good communication effect. Understanding Japanese corporate culture can help students engage more quickly into the Japanese enterprise work and deal with the relationship with Japanese companies more properly.

Therefore, teachers in the usual daily teaching should simulate more vivid business situation, stimulate students' learning enthusiasm and initiative and cultivate students to solve the problems in the learning process. Business Japanese teachers should use advanced teaching method, make rational use of multimedia technology to teach students and create interesting and vivid situation of life in the teaching process, which is able to let students master the specific application of language and communication skills in the actual situation, improve their professional quality and finally make the students fully understand Japanese culture and the dynamic development of Japanese. Using multimedia tools can make students have more opportunity in the whole teaching process, which benefits the use of language and practice. Because of the auxiliary teaching such as pictures and video, students are obviously concentrating on class and enhance their perceptual knowledge of context and language communication.

Second, in order to improve the students' practical ability, teachers can simulate business activities in Japanese class and let the students speak Japanese in the whole dialogue. Japanese business activities include simulation reception room and shopping commodity sales, letting the students as soon as possible form a certain cognitive to the commercial activities, experience professional life and play to their creativity and initiative, in this way, students are also able to learn how to apply the theoretical knowledge to solve problems in reality[5][6]. Through experiencing the simulated business activities, students can have a better understanding of the professional nouns and professional term, so as to better grasp the skills to relate to others. In the teaching form, discussion and debate can fully mobilize the classroom atmosphere, let the students think positively and fully grasp the special difficulties in the textbook. In order to make students better understand the career planning in the future, teachers can invite Japanese executives into the classroom to explain the current management status and the future development trend of Japanese companies and their need to what kind of talents through the school teaching platform, so that the students can become more purposeful and targeted in the future study.

\section{CONCLUSION}

Traditional business Japanese teaching methods have been unable to meet the needs of students. Under the developing background of the new era, more and more requirements for business Japanese talents are put forward. To this end, college teachers must set clear of business Japanese teaching goals in the process of cultivating talents, constantly adjust the course structure and update the course content. In addition, teaching methods should also be enriched because only innovation of teaching methods can meet the social demand for business Japanese talents.

\section{REFERENCES}

[1] Liu Wei, Wu Yan.2004. Selected works of international business Japanese[M]. Nankai University Press

[2] ]Wu Yimin,2010. Practice and exploration of action-oriented mode in the series of business Japanese courses--Centering on the project teaching method[J]. Journal of Guangzhou City Polytechnic(2).p : 96100

[3] Wang Ying, Yin Rui.2009. Construction and optimization of business Japanese curriculum[J] Education Science \& Culture Magazine.

[4] Zhang Yijuan. 2006. The application of non-verbal communication in cross-cultural business communication-A new approach to business Japanese teaching[J]. Japanese Study and Research. 
[5] Liu Bin. Curriculum setting and teaching content reform approaches of business Japanese in higher vocational colleges. 2010. Bulletin of Hunan Medical University.
[6] Xu Jingying. 2013. Contemporary business Japanese teaching innovation research[J]. Technology Review. 